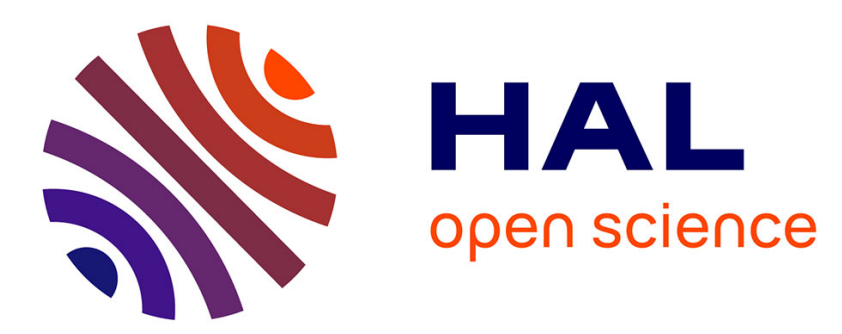

\title{
Migration-religion studies in France: evolving toward a religious anthropology of movement
}

\author{
Sophie Bava
}

\section{To cite this version:}

Sophie Bava. Migration-religion studies in France: evolving toward a religious anthropology of movement. Annual Review of Anthropology, 2011. ird-02067947

\section{HAL Id: ird-02067947 \\ https://hal.ird.fr/ird-02067947}

Submitted on 14 Mar 2019

HAL is a multi-disciplinary open access archive for the deposit and dissemination of scientific research documents, whether they are published or not. The documents may come from teaching and research institutions in France or abroad, or from public or private research centers.
L'archive ouverte pluridisciplinaire HAL, est destinée au dépôt et à la diffusion de documents scientifiques de niveau recherche, publiés ou non, émanant des établissements d'enseignement et de recherche français ou étrangers, des laboratoires publics ou privés. 


\section{Migration - Religion Studies in France:}

\section{Evolving Toward a Religious Anthropology of Movement}

Sophie Bava, IRD / LPED / Cairo University

sophie.bava@ird.fr

Shortened running title:

Migration-Religion Studies in France 


\section{TABLE OF CONTENTS}

Introduction: Men of God and Migrants

1. When migrants arrive... and religion follows

2. From "Islam in France" to Islam as it is experienced. Toward an anthropological approach to religious practices in a migratory context

3. Migrants and religions in movement

4. Some tools for the construction of an appropriate analytical framework for the religion-migration scene

Conclusion: Toward a religious anthropology of movement

\section{KEYWORDS}

Migratory itinerary/trajectory/journey

Mobility

Religious practices

Africa

Islam

Religious transnationalism 


\begin{abstract}
As the emergence and visibility of the religious on the African and European migratory scenes is generating much debate, this article explores how scientific thought and analysis of the subject of "religion-migration" has gradually been built up in France. Over three decades, the developing academic debate about issues of migration, identity, then religion within migration, and migrants' religion, has revealed many tensions, especially about the question of Islam and/or religious minorities within migration.

Through selective review of these debates, I attempt to comprehend perceptions and research about the religion-migration scene since the 1980s. From an anthropologist's viewpoint, I also explore whether studies of African migrations in France have opened the door to a new research field in terms of method and inquiry. Thus, as we will observe, anthropologists of African migrations have enabled us to reexamine the object of religion within migration, and remove it from an ethnicizing, identity-based approach.
\end{abstract}




\section{Introduction: Men of God and Migrants}

By championing the cause of immigrants, clergymen ${ }^{1}$ prepared the ground for the study of migration in France in the mid-twentieth century, through the organizations they managed. Since then, the relationship between migration and religion in the French scientific field has evolved and has brought depth to many debates through the last few decades. Today, as migration continues to make front-page news in the field of European politics, re-examination of the links between migration and religion will prove valuable to the achievement of a better understanding of migratory itineraries. Studies of the redefinition of migration routes, of territories crossed and taken over again by migrants, and of the plurality of protagonists and networks often show that religious processes are at the core of migratory practices and that migration is at the heart of religious issues. The transformation of social and economic practices by and within migration, as well as the redefinition of religious practices by and for migrants, also support this thesis. Hence, one may speak of religion within migration, of the religion of migrants or of migrating religions, depending on whether one seeks to explore the evolution of migratory practices, of migrants' religious strategies or of the transnational religious institutions that receive migrants.

Though approaches may differ, they still serve to probe the same reality, which I propose to explore here through an overview of the scientific debates that drive researchers in this field, particularly with regard to the question of migration and Islam in France. I will address the

\footnotetext{
${ }^{1}$ In particular, I am referring to the founder of the journal Hommes et Migrations ("Men and Migration"), Father Jacques Ghys of the missionary order of the White Fathers, who created Amana (Assistance morale et aide aux Nord-Africains), an association for aid and mutual assistance for North Africans with a focus on literacy training. He also launched the journals Études sociales nord-africaines (Esna) and Cahiers Nord-Africains. French protagonists in this field included CIMADE (an NGO created by French Protestant student groups at the beginning of the Second World War, to assist and support people displaced by war) which was specialized in migrant rights, and the Pastorale des Migrants (a department of the Catholic Church), whose action, expertise and news reports are also a source of information.
} 
transition from the issue of immigrants to that of migrants, and from the matter of religious identity during migration to that of the circulation of transnational religions and hyphenated identities (Assayag \& Bénéï 2000: 18). Thus doing, I will attempt to determine a research model for the religion-migration issue that would allow us to remain as close to empirical reality as possible without ethnicizing the models we study, nor essentializing the processes we observe.

\section{When migrants arrive... and religion follows}

Since the end of the nineteenth century, several long-standing waves of immigration have epitomized the populating of France (Noiriel 1987). After INED (the French National Institute of Demographic Studies) carried out some initial studies of the assimilation of Italian and Polish immigrants in the early 1950s (Girard \& Stoezel 1953), André Michel's research on Algerian workers in France (1956) first dealt with immigration on a sociological level. However, it was not until the late 1960s that a research trend associated with social work and training undertook to observe the living conditions of immigrant workers (employment, housing, education, health and family-related aspects). ${ }^{2}$ Only by the end of the 1980 s did this truly become a pivotal research object in the French scientific field.

At first, politicians used the term "assimilation" when they discussed immigration; then by the end of the 1970s, they began building their discourse on the notions of "insertion sociale" ("social inclusion," or becoming well-connected in society) of immigrants, and their "intégration" (within the French nation). The use of the second term later became a matter of

\footnotetext{
2 These studies appeared in Migrants Formation, a journal launched in 1973, and which is now called Diversité, Ville, Ecole, Intégration.
} 
consensus across the political spectrum (Gaspard 1992). From an initial focus on the figure of the "immigrant worker" who must integrate into the French nation, this field of scientific research then came to include "the French model of integration and assimilation" in the analysis of living conditions of the immigrant population in France.

Thus, immigrants became a social category (Spire 1999)33: different ethnic groups and their ways of managing social practices - be they matrimonial, community-related, cultural or religious - began to be classified. The risk involved in this was that social relationships might be ethnicized due to decontextualization of the groups being studied, and that a discourse of difference might be reinforced at the expense of discourse about the wealth of diversity and interaction. Nonetheless, these first analyses did allow these groups to exist socially and statistically. In France, studies about migration are disputed; "immigration" is an object too closely related to the political and administrative management of populations and it remains problematic in the scientific field, because it calls the French republican model directly into question with regard to how this model relates to the Other, to foreigners (Schnapper 1991).

As A. Sayad wrote with respect to immigration, the first issue involved in the study of this object "is that it poses problems." To Sayad, assimilation was an ethno-centered practice, a "colonization of the interior," and he developed a sociology of immigrant workers' living conditions through a more micro-sociological approach, more attentive to the practices of daily life and to individuals' singular experiences. He was among the first to take an interest in the trajectory from being an emigrant to being an immigrant, and especially in the political conditions in which this working-class migration had been produced. Sayad considered his

3 The term "immigrant" became a social category in France in the early 1990s when the Haut Conseil à l'Intégration (High Council for Integration) defined it as meaning "any person born a foreign national, in a foreign country, who resides in France" (A Spire 1999: 50). However, this categorization was first applied to statistical data before it was introduced and used in sociological debate. 
fieldwork had shown how absence itself gives immigrants' territory meaning: they are "double absentees," "neither from here, nor from there," though they are both emigrants and immigrants at the same time.

After the notion of integration, he addressed that of breaking away (or severance) through the meaning immigrants give to their own migration, more than to their social trajectories. Even though in his eyes, an immigrant had a life trajectory and a memory of his/her history, as well as daily practices in the fields of housing, health and religion, and a political role, Sayad did not consider the relevance of the question of religion in the context of migration.

In the 1980s, the State took possession of this debate in response to a growing demand for knowledge about the immigrant population and living conditions in France, coming from social workers, employees of the education and health systems, and administrative personnel (Kuczynski \& Razy 2009). It issued calls for project proposals, mostly through State structures such as FAS, ${ }^{4} \mathrm{DPM}^{5}$ and $\mathrm{CNDP},{ }^{6}$ and through community organizations, many of which were funded by the aforementioned entities. These organizations launched several journals, including Migrants-formation, Migrations-santé, Migrations-Etudes, Migrationssociété and Hommes \& Migrations.

From the 1980s on, sociologists and anthropologists such as Catherine Quiminal, Jacques Barou and A. Moustafa Diop also began to organize their research so as to focus on both

\footnotetext{
4 The Fonds d'Action sociale (Social Action Fund) or FAS, for immigrant workers and their families, was created during the Algerian war of independence and then evolved in several different ways; it was dissolved in 2010. In addition to the social support of immigrants and the funding of social and cultural projects, it also oversaw several studies of migrants' living conditions in France.

5 DPM stands for Direction de la Population et des Migrations (Department of Population and Migrations).

6 CNDP stands for Centre National de Documentation Pédagogique (National Center of Pedagogical Documentation).
} 
spaces of migration, ${ }^{7}$ instead of on immigrants in France only. They proved more systematic in addressing the social, cultural and religious communal practices of ethnic groups like the Soninké and the Manjak, as well as the Senegalese Murides (a Sufi brotherhood), between the countries they departed from and their host countries. In the Foyers de Travailleurs Migrants (Migrant Workers' Hostels), these researchers observed African migrants' initiatives such as the organization of village community funds, and life inside village-based and urban associations, as well as cultural and religious practices.

During this period - the late 1980s - which witnessed the beginnings of academic inquiry into multicultural society, sociologists and political scientists took an interest in the religion of the "immigrant" Other. These were the first studies of Islam in suburban France, in hostels and prayer rooms; furthermore, they comprised the assumption that immigrants needed to be able to practice their religion in decent conditions and to experience their cultures fully, within French society. However, they did not analyze immigrants as fully-fledged protagonists of their religion, nor did they observe the diversity of religious options on offer due to migration or simply on the transnational religious market. One might consider that sociologists made too strong an assumption that migration was permanent and therefore, saw religion as one of many transplanted values that would (or must) adapt to the French secular model.

Thus, the academic debate came together by the end of the 1980 s, centering on the theme of ethnic minorities and religious identities. Andezian, Dassetto, Bastenier, Saint-Blancat, Cesari and Kastoryano were some of the many authors who studied Islam among migrants. Political scientists such as Olivier Roy and Gilles Kepel, on the other hand, took an interest in the

\footnotetext{
7 Translator's note: The expression "espaces de migration," translated as "spaces of migration," refers to the places people emigrate from, and the places they migrate to.
} 
details of the history of Islam in France, as well as in the influence of Muslim intellectuals from the Arab world among French Muslims.

\section{From "Islam in France" to Islam as it is experienced. Toward an anthropological approach to religious practices in a migratory context}

As Babès observed in her article about "identities reshaping themselves [recompositions identitaires] within Islam in France” (Babès 1995), "Thus, in a curious paradox, Islam ends up being both over-publicized and a forgotten religion." Several approaches have been combined in the debate about Islam in France, with a view to analyzing Islam through the 'veil' of integration and the question of secularization [laïcisation in French] in France, while emphasizing the paradoxes involved in the French mode of integration (Hervieu-Léger 1996, Saint-Blancat 1995). 'Immigrant' social groups such as women (Lacoste Dujardin 1997), suburban youth and religious associations have been studied (Cesari 1994) through the spectra of different generations of migrants and of the evolution of religious practices. To the 'elders', there was no need to call for a space for holding prayers, as long as the questions of transmission [of religion] to their children, or of one's own death, were not posed. As for younger groups, born in France, the process has proved different because Islam is also their culture and they wish to display it, by creating associations, for example.

Amel Boubakeur (2007:16) has defined re-Islamization as "the fact of experiencing a religious socialization, not inherited from one's Muslim parents, but acquired pro-actively by frequenting religious movements, places of worship and peer groups such as young Muslims' associations." Conducting research about the groups and organizations acting as protagonists in the process of re-Islamization was characteristic of the change in focus within one section 
of the research community in this field. They dealt with the questions of the transmission, inheritance and production of Islamic discourse within populations ranging from the Islamic elites from Muslim countries that were influential within France in the 1990s and 2000s, to reIslamized youth invested in the renewal of Islamic modes of mobilization through culture, art, music, literature... (Amghar 2006, Bowen 2004, Boubakeur 2007, Göle 2002)

Though research about Islam in France today still tends to be somewhat entangled in the debate about integration, nonetheless, many studies already initiated by anthropologists by the end of the 1990s, have opened the way to learning about Islam as it is experienced. These studies call for an approach to Islam in terms of social practices, ritual practices and how places of worship are organized (Geisser 2001, Bava 2002, Kuczynski 2002), the conditions in which halal meat is produced, how the al-"Aid al-Kebir festival is organized in French urban space (Bonte et al. 1998 and 1999), the meaning believers invest in their religious practices (Saint-Blancat 1997) and the links between economic networks and religion (Bava 2003). What motivates these researchers is no longer an approach in terms of integration, but the objective of actual knowledge of migrants' Islam, through knowledge of elements of continuity between the migrants' countries of origin and those they migrate to. Though this knowledge is not disconnected from French national identity, it still remains tied to the definition of a "French Muslim identity" or, as Bastenier (1998) put it, an "ethnic consciousness," in the sense that religion is construed as an element of ethnicity, an element of migrants' identities. Approaching the religious dimension among other attributes of identity, and observing the freedom individuals may have to define themselves through their own memories as much as in relation to others and to the societies they pass though or enter into - this is what researchers must address. Though society tends to impose certain models, migrants also construct their own references. 
These works demonstrate that it is difficult to make the religious sphere function within previously established borders, like those of the "territory of integration," for example. If we attempt to enclose belief in Republican, ethnic, cultural and legal borders (i.e. the right to practice one's religion), it is no longer discernible, and the "immigration-Islam" dyad will remain unproductive (Andezian 2001). Hence, to apprehend Islam as it is lived, one must allow for the diversity of ways religion is expressed by the Muslim population, as well as the representations and practices of actors in this field. By observing that immigrants are also migrants in motion across at least two territories, this research is gradually integrating improved knowledge of Islam from both sides of migration, and also of transnational networks that transcend national borders.

However, some studies have still proved excessively one-sided and failed into account to take the historicity of the movements under observation, as if migrants' religious constructs were decoupled from Islam as they had experienced it in their own countries, and from the international or transnational Islamic community. The latter has often appeared in the shape of a kind of "transplanted" Islam, negotiated with local society. Timera's work on the Soninké in France (1996), Andezian's study of female members of the 'Îsâwiyya Sufi brotherhood in France and Algeria (1983), as well as my own on Muride migrants (2000, 2002, 2003, 2004, 2006) all take this dimension into account, recognizing the importance of having previous knowledge of the object one is studying, as well as being able to see it comparatively, so as to better appreciate transformations. This multi-situated approach, involving going back and forth and comparing, allows one to avoid mistaking pre-existing practices from migrants' countries of origin for new religious constructs and reshaped practices. By opting for this posture, researchers focusing on Muslim migrants in France have been confronted with another considerable issue: the difficulty of contrasting disciplinary fields and cultural 
spheres. Islam in a migratory context is not a field that has attracted scholars specialized in the study of Islam itself, and the same disconnect can be observed between those who study the "real" Islam in its countries of origin, and those who study hybrid forms of Islam as they are reshaped through migration. This split is reminiscent of a model in classical Islamic studies, a field in which, as Andezian (2002) has noted, "this two-level model has been widely over-used and abused, so as to distinguish 'learned, scriptural, orthodox Islam' from local expressions of the religion, described as 'vestiges of the pre-Islamic age'." (Andézian 2001: 18)

Thus, religious referents and identity-related referents have been put into perspective, and sometimes confused with one another in most studies which, since the 1980s, have mainly been focused on Islam. However, as migration and the interactions it brings about tend to amplify these processes of confusion of religious referents and identity-related referents, considering religious constructs over several territories has appeared essential. Working on the question of religion within migration, particularly within migration considered both from the perspective of its fluidity and of its perennial or recurring aspects, requires one to accept this back-and-forth dynamic, that of exchange between the purported "authenticity" attributed to historic religions, and the religious trajectories of each migrant and each movement observed. After analyzing a transplanted form of Islam, one may opt to analyze "transmigrant" Islam. To Grafmeyer,

\footnotetext{
The very issue of integration can become an obstacle to analysis from the moment we make it an end in itself. To newly-arrived persons as to already well-established city dwellers, the ability to put several territories and ways of belonging into play, may well constitute a resource in the long term, both for mastery of the locations they have settled into and for maintenance of group identity. (Y.
} Grafmeyer, 1994, Sociologie Urbaine, p.87) 
This change from an assimilationist approach to migratory flows to one highlighting transnational processes, appears clearly through observation of the manner in which sociologists and anthropologists have gradually proceeded to integrate the question of movement and mobility in studies about migrants and religion.

\section{Migrants and religions in movement}

Since the early 1980s, studies of transnational migrations have begun to gradually integrate a trans-cultural approach into the comprehension of migratory trajectories. At the same time, the transnational approach to religious phenomena has brought a new understanding of religions "in the context of migration."

Indeed, the past twenty-odd years have witnessed a theoretical renewal of research about the notion of migration. Today, migration is treated much less as a form of severance or as a succession of places, and it is no longer interpreted as an uprooting or a process of acculturation. English-language (Glick-Schiller et al. 1992) and French-language studies (Tarrius, Peraldi) centered on migrant entrepreneurs have introduced the notion of transnationalism ${ }^{8}$ as a new grid for analysis of the migratory field. In this sense, as Capone has observed, “'Transnationalism' is not a new phenomenon, but rather a 'new perspective.' "Thus, 'the transnational lens' now allows us to apprehend phenomena that were not intelligible in the past.” (Capone 2010)

8 “...the process by which immigrants forge and maintain multiple and interconnected (multi-stranded) social relationships linking their societies of origin and their host societies. We call these processes transnationalism in order to underline the fact that nowadays, many immigrants construct social fields stretching across geographical, cultural and political boundaries." (Glick-Schiller et al. 1992: 6) 
These studies have introduced the terms "transnational migrants," "transmigrants," and "migrants involved in pendular or circular mobility" (Tarrius 1989). In this context, their objective is to describe the relational territory staged by strangers, the territories they connect to each other in a transnational sphere; these connections can be economic in character, or also cultural or religious. In this sense, migration is no longer approached solely in terms of cost, but rather in terms of resources, skills and benefits produced by comings and goings between two or more countries. This "ability to circulate" ("savoir circuler"), to use Tarrius' expression (1996) and this mobility may be analyzed as a social phenomenon that creates wealth, but also produces an imagined world and religious constructs stretching across different worlds.

At the meeting-point between anthropologists, English-language sociologists and immigration sociologists in France, a third avenue has opened up based on socio-anthropology applied to the study of migrants through the combined relationship of spaces they cross and/or those they settle in. Researchers transcend issues of assimilation, integration and/or severance, and they diversify their methods of observation, which allow migrants to exist socially in their eyes as a group creating its own economic, social, religious and imaginary networks between several territories. Extending English-language research on "ethnic business" initiated in the 1970s (Bonachich \& Modell, Clifford, Granovetter, Portes, Waldinger and Zhou), French researchers have explored these new directions. This has given rise to an entire tradition of research about migrants as economic protagonists in the city (Battegay, Bertoncello \& Bredeloup, Boubakri, Ma-Mung, Peraldi, Salem, Sassen, Tarrius, Ebin and Schmidt di Friedberg) which has been taking root in French-language research since the 1990s. 
Thus, scholars observe strategies implemented by migrants and entrepreneurial chains that shape circuits of economic activity; they use the notions of skills, transmission and experience. They discuss the types of resources protagonists mobilize, as well as transnational social capital, multiple social networks and networks of intercommunity exchange. Directly from this emerged the question of the role of religious networks, such as those of the Muride, in the development of transnational economic activity. This anthropology of migration, first initiated by phenomenology, then by a "socio-anthropology" of migrants' economic practices that promoted an "anthropology of movement" (Tarrius 1989), has shifted the object of research and overturned it to give researchers a broader perspective, so as to observe migrants as producers of new social rationalities and new territories. From this point of view, migrants' territory has fleshed out and multiplied as scholarly perspectives have passed from the ethnic territory to the "circulatory territory," a "notion which records the socialization of spaces as frames for practices of mobility" (Tarrius 2001: 45). It also reveals much about the break with assimilationist research about migration. Without dismissing questions of appropriation or of symbolic space, the notion of circulatory territory also brings in considerations of social rhythms, identity processes, imagined spheres, customs, practices, interactions and negotiation. Thus, spaces of migration are invested with meaning. This approach has proved essential, especially in the understanding of processes of cultural and religious transnationalism. The figure of the stranger - as a transmigrant, a nomad or someone who has settled in - is becoming multiple and being consolidated, but the observation of identityrelated constructs and of "ethnoscapes" (Appadurai 1991) has stagnated and exerted a divisive effect on the academic sphere.

To Appadurai, who evokes "transnational cultural flows" leading to the deployment of "cosmopolitan cultural forms," it is "urgent to pay closer attention to the cultural dynamic of 
what is now called deterritorialization" (Appadurai 1996: 90). Yet these studies focusing on the analysis of transnational cultural flows through observation of the "cosmopolitan cultural forms of the modern world" like flows of goods in a vast supermarket, cast doubt on migrants' cultures of origin. So doing, they risk reproducing existing identity-related tension rather than analyzing it as a negotiated process, and have provoked many objections (Stuart Hall 1998, Assayag 1998, Friedman 1994). Authors such as Ebaugh \& Chavetz, GlickSchiller et al. and Hagan \& Clifford have also influenced French academic work, in which the notions of globalization and transnationalization are debated (Capone 2004). The transnational dimension of the religious field is particularly representative of this discussion, as Levitt \& Glick-Schiller (2004) have shown in the United States by underlining the emergence of a transnational religious field and transnational religious networks elaborated or called up by migrants. In France, however, research on the subject of religious transnationalizations and transnational churches, as well as their practices and discourse, and the religious constructs of migrants, is scarce.

Religion marks the different stages of migratory itineraries and conversely, migrants' religions are rooted in their countries of origin. Especially through studies of Islam and Christianity, we know that transnational religions are not only carried by migrants and converts; yet we cannot ignore the latter's role in the countries in which they settle. Hence, it appears crucial to keep in mind that the theoretical frameworks developed by studies of international migration enable us to better understand transnational religious processes.

Thus, in France, the religious baggage that migrants carry with them is gradually being dissected, and researchers have been analyzing its content while simultaneously observing religious constructs and religious forms of belonging across several territories. If we use the 
term "transnational spaces," then the religious sphere produces continuity among discontinuous transnational spaces, and migrants are often a vector of this continuity. In fact, it has promptly attracted the attention of political scientists studying Islam in France. John R. Bowen has examined the fact that in Europe, Islam stretches beyond borders (Bowen 2004), and that Islamic norms are produced within a transnational public spacce (Bowen 2004, Amiraux 2004, Caeiro 2003).

Studies of Muridism constitute a particularly instructive example of this type of scholarship, at the crossroads of transnational migration and religion. My own research has shown that economic migrants initially delocalized their religion in response to demands from their community, not to demands from the religious hierarchy (Bava 2000, Ebin 1993, Riccio 2001). This delocalization crystallized around the creation of Muride associations and the opening of places of worship, including the Sérigne Touba houses for the accommodation of sheikhs and worshippers and the teaching of Muridism to children (Bava 2003, 2004). It also materialized through organization of itinerant sheikhs' travel to come meet the taalibés (followers of the Muride creed), and of pilgrimage trips to the holy city of Touba, which in return, also transformed religious practices there (Bava \& Gueye, 2001). Furthermore, migrants have taken hold of religion to re-symbolize their own migratory paths. These paths can take on a different religious meaning, depending on whether the migrant is in a destination country to settle in, such as France, Italy or the USA, or if he/she is situated in an area of more or less extended transit, such as Niamey in Niger, or Cairo in Egypt (Bava 2006).

These economic entrepreneurs, who have created the basis for a transnational organization based on an extension of their religion, have become de facto religious entrepreneurs in the 
migratory context. The Murides have created the bases of their spiritual life themselves, and in the places they pass through, their religious identity has become the trump card of their migrations, as well as their local and transnational activities. Beforehand, there had been no pre-existent transnational religious organization managing the spiritual side or the public side of this network. In an initial phase, Murides gradually made the non-international dimension of their brotherhood a strength, as their own mobility has created a transnational network run by a multitude of individuals in various countries. Nonetheless, their common reference point still remains Touba (Senegal), their holy city and the headquarters of their religious hierarchy. Migrants have constructed a transnational religious identity that reinforces group cohesion while also allowing them to fit into the countries they migrate to, and to extend the brotherhood's boundaries (Bava 2002, Ebin 1990, Gueye 2002, Schmidt di Friedberg, 1994). All the necessary elements are present in this case to allow us to describe the place of religion in transnational migration, and the role played by migrants in the development of a transnational religious system. Levitt (2003) has observed that "religion plays a critical role in identity construction, meaning making, and value formation," but religion is also objectively and/or symbolically constitutive of migratory paths themselves. In fact, religion is not only a burden or a resource (material and spiritual), or a value for migrants in exile to take refuge in. It actually generates specific trajectories, new protagonist figures and renewed religious experiences, and it opens the way for unprecedented religious constructs in new spaces (reterritorializations) or in religious spaces revived by the arrival of migrants. Hence, the impact of religious references, but also of religious spaces, in the very constitution of migratory trajectories is considerable. Some religious networks are even the source of mobility and often of migration, such as the network of Islamic studies between Black Africa and the Arab world (Bava 2009), for example, or Catholic networks for facilitating the arrival and placement of certain migrants in specific employment niches, such as domestic labor. 
Though this type of analysis favors migrant's own point of view (and the bottom-up approach), as a protagonist of his/her religion within migration, composing a religion between several territories, one must not neglect the standpoint of international religious institutions (religious training networks, Churches, $\mathrm{NGOs}^{9}$ ) unattached to any particular nation-state, either. These institutions are aware of the importance of migration to the dissemination of their models and territories, as well as to the attraction of worshippers. This is the case for evangelical churches and other forms of Christianity of the global South (Mary 2009), which reach out to African migrants in Europe, but are also expanding along migration routes, as one may observe in Cairo (Bava \& Picard 2010).

But are migrants always aware of belonging to religious networks? According to Levitt and Glick-Schiller (2004: 1006) a research approach in terms of transnational social fields must distinguish between the existence of transnational networks and individuals' awareness of belonging to such social configurations. Belonging to a social field means developing "practices that signal or enact an identity which demonstrates a conscious connection to a particular group," which may be located beyond the national borders of the country a migrant has settled in (Levitt \& Glick-Schiller 2004: 1010).

Studies of transnational Islam further explore this question of belonging to a transnational network. Bowen's thesis underlining how the public transnational space of Islam goes beyond migration is of interest because it reminds us of the importance of mastery of the texts, norms and symbols produced by the thinkers of contemporary Islam, particularly when this production addresses the question of people's movement across non-Muslim lands and

\footnotetext{
${ }^{9}$ In this case, we mean NGOs based on a religious denomination.
} 
Muslims' lives there. These norms are constantly reactivated and debated but the knowledge of networks of Muslim scholars who participate in debate about the production of Islamic norms adapted to migratory phenomena is most significant. This leads Bowen to state that in order to comprehend the transnationality of Islam, one must go further than the mere study of migration: "It has to do much more with the worldwide communication of ideas than with the movement of population, and does not depend on it." (Bowen 2004)

On this point, in view of studies carried out on the religion-migration theme, I still consider that we should not adopt a dichotomous point of view about scientific approaches, but rather attempt a combined approach to religious movement through populations, ideas, objects, texts, territories, etc. Of course, we should also strive to be conversant with the specific codes of the movements we study. The mistake we must avoid at all costs in research about religion, be it Islam, Christianity or Judaism (and sub-groups within these religions), is essentializing this discussion by cutting ourselves off from the debate about migration.

Analysis of migration-religion connections constantly oscillates between our view of migrating religious groups recreating the fabric of community, constituting a diaspora and bringing identity politics into play on the one hand, and our view of religious transnationalism, renewing cosmopolitanism and transcending nation-states and the frontiers of identity, on the other. As Stefania Capone (2010) has remarked, "the transnational does not preclude the production of essentialist discourse." These two aspects must always be measured, so that we may correctly understand how migration shapes the religious dimension, and vice versa. In the case of Islam, over the past decade, scholarly debate opening up to new forms of globalized Islam (Boubakeur 2007, Haenni 2005) has proved particularly rich, and 
all the more so for having compared movement within Islam to movements within transnational Churches.

To analyze these effects and these constructs situated at the conjunction of migration and religion, we must certainly be familiar with the religious movements we are observing, so as not to perceive pre-existing phenomena as new ones, but we must also be sufficiently conversant with the groups of migrants we are studying, as well as their trajectories. Our observations must be multi-situated, but we must also measure the scales and different levels governing these migrations, in order to determine the role of the religious sphere, of religious institutions and NGOs in building migratory circuits. For example, we may shed light on the emergence of a market for religious goods in the transit areas frequented by migrants. On the methodological level, favoring an approach that interconnects migratory paths and religious itineraries will allow us to work in closer contact to these mobile objects. We may observe that religion, religious networks and institutions may be used on the one hand, for mobility (both upstream and downstream) and on the other, for the justification or resymbolization of migratory trajectories. In between the two, they may be used for living, that is, entering social and urban spaces and negotiating one's place in them, or even restructuring them.

Hence, we would be proceeding toward a religious anthropology of movement combining migration issues and transnational religious processes. This would mean focusing just as much on believers' itineraries and careers as on texts, objects and figures of mobility via religion, such as pilgrimages, religious migration, the circulation of religious objects, and religious networks and institutions. However, whatever approach we select to these transnationalizations of migrants and religions, it remains essential to build a multi- 
disciplinary analytical framework, between mobility, transit and anchorage, to allow us to combine these approaches.

4. Some tools for the construction of an appropriate analytical framework for the religionmigration scene

First of all, let us begin with a few observations which should lead us to certain scientific questions, starting with the impact of transnational religions upon the circulation of migrants. The dynamics by which religious institutions are set up, allow us to analyze the hierarchical relationships within a distinct sphere, and to comprehend the designs of particular institutions. In addition, the observation of religious businesses and NGOs placing themselves on migration routes teaches us more about geopolitical questions, but also about the ability of certain enterprises to implant themselves transnationally and to adapt to migrants' issues, so as to open up their markets (such as transnational religions and religious training networks, for example). On the other hand, this impact must also be analyzed at the level of migrant protagonists themselves, who insert themselves into these networks with specific goals in mind: material or spiritual support, and reinforcement of connections with the country they have migrated to, but also to their country of origin. This conjunction may lead us to observe the deployment of an actual religious and spiritual market, at the crossroads of migratory routes and religious spaces.

We must also study the influence of migrations on religious practices in a given country. Starting from analysis of the delocalization and relocalization of worship, its revitalization, the organization of particular religious events and the meaning of certain religious events and practices, we may analyze the connections between migrants' religious practices and local 
society. This may also allow us to understand how a transnational religious space is renegotiated.

The examination of religious figures of migration also informs us about the different protagonist figures at the crossroads of religion and migration. These include religious leaders who create churches or religious groups, religious leaders who follow migrants (missionary pastors/ministers, itinerant sheikhs, Muslim leaders), students of religion who travel for training purposes, or adventurers who opt for a religious affiliation, or even a conversion, so as to try their luck in a different manner. They also comprise migrants who combine religious identity and economic activities to enhance their business, and volunteer-sector actors (from NGOs) who place themselves in locations that migrants pass through or settle into. All these are examples of religious figures constituted by migration, or in migration.

Observation of how spaces are transformed by migrants' religious practices informs us about territories of the religious sphere, the strategic dynamics underpinning their extension and transnationalization, the logic of migration which revitalizes some of them, as well as the pilgrimage dynamics which bring inactive religious sites back to life. These new religious topographies set up by or for the creation of new reference points for migrants, also modify urban space and the way people relate to borders and to nation-states.

Further, the scrutiny of spiritual dynamics and specific religious practices functioning within migratory experiences, such as the logic of migrants' conversion, the accumulation of multiple facets of religious belonging, "sampling" of various religious options and other patchwork-style constructs made during migration, may enable us to improve our understanding of the impact of migrations on individual religious experiences. Similarly, the 
observation of the links between migrants' economic and religious practices informs us about the entrepreneurial dimension of migrations and about the role of social networks - including religious networks - in these migratory practices.

To this non-exhaustive list of observations, we should add transversal thinking. We suggest various axes of transversal thought about this field below, to be taken as different possible indications allowing us to apprehend the meaning of these transformations occurring on the religion-migration scene.

First, religion may be perceived as a resource within migration - a spiritual, material and imaginary resource. It may offer one comfort or assistance with entry into a network of local sociability; it may allow one to find employment, to maintain connections with one's country of origin (transnational community); it may also help migrants to create economic activity, etc.

Yet migrants may also be perceived as a "resource" by religious institutions. As worshippers or followers, their joining the faith produces a triple effect: extension of these institutions' territories, increasing their flock and bringing in funds.

Besides, religion may also be considered as supporting migration and more temporary forms of mobility, in the case of religious training and internships, or religious tourism, for example. Occasionally, migration itself is assimilated to a religious practice through a form of imitation, like when a Muslim migrant perceives his/her migration in reference to the Prophet's exile to Medina, for example, or in the framework of certain pilgrimages. Religion may then be considered as a symbolic resource, an instrument for re-symbolization of migratory journeys after the fact.

Religious movements also adapt to the religious practices of the migrant members of their community, which causes alteration: changing the location of the movement's headquarters, 
adapting liturgy and symbolic references or even - indirectly - religious practices. Indeed, the mobility of a religion's followers induces change and also involves other actors, such as community activists, men of the cloth - who are sometimes also researchers - and initiatives or associations for the reception of migrants.

Thus, several combinations are possible and may allow us to better examine the linkages between religion and migration, via transnational religions, the religious practices of migrants, and religious organizations along migration routes, just to mention a few pathways of investigation. The most suitable method for apprehending the depth of connections between migration and religion between several spaces is a multi-situated and comparative ethnographic approach. Without observing the different connections produced by migrants, an anthropologist of migration pursues his/her object from multiple spheres. He/she must be acquainted with the types of symbolic material brought into play, examine the transformations taking place, compare and contrast trajectories and networks, study religious institutions over several spaces, and know how to move within these transnational social spheres without neglecting the significance of how his/her observations are anchored.

\section{Conclusion: Toward a religious anthropology of movement}

Consequently, should we chart religions or follow migrants? As we have seen, both methods have scientific objectives which often differ; nonetheless, it appears necessary to combine them. Proceeding from studies of religion within migration and of transnational religions, we have witnessed the building of a research trend centered on a form of anthropology of migrations and of a religious anthropology of movement. The latter has focused equally on 
believers' itineraries and the histories of religious institutions, and on figures and objects of religious mobility (pilgrimages, studies, texts, migration, religious networks, means of communication, circulation of religious items...) between the poles of mobility and fixedness.

In my view, anthropologists' knowledge of migrants' societies of origin has made a considerable contribution to the understanding of these religious processes straddling several territories. Yet it could not have progressed so successfully without the full scope of research carried out by historians, sociologists and political scientists studying migrations. Exempted from debates about the French republic - perhaps due to their mobility and their presumed belonging to another cultural sphere - anthropologists of migration in France already possessed the necessary instruments to ponder this question of cultural and religious transnationalisms. Without completely disregarding debates about identity, they have shifted their focus in order to better explore the migration-religion-identity relationship, starting from migrants themselves and the multiplicity of spaces they cross. 


\section{Literature Cited}

Allievi S. 1998. Convertis à l'Islam. Les Nouveaux Musulmans d'Europe. Paris: L'Harmattan, 383pp.

Allievi S, Nielsen J. 2003. Muslim Networks and Transnational Communities in and across

Europe. Leiden \& Boston: Brill

Amghar S, ed. 2006. Islamismes d'Occident. Etat des Lieux et Perspectives. Paris: Lignes de Repère.

Amiraux V. 2004. Les Musulmans dans l'espace politique européen. La délicate expérience du pluralisme confessionnel, 20ème Siècle 82:119-130.

Andezian S. 1983. Pratiques féminines de l'islam en France. Arch. Sci. Soc. Relig. 55(1):5366

Andezian S. 2001. Expériences du Divin dans l'Algérie Contemporaine. Adeptes des Saints dans la Région de Tlemcen. Paris: CNRS Ed.

Appadurai A. 1991. Global ethnoscapes: notes and queries for a transnational anthropology. In Recapturing Anthropology: Working in the Present, ed. RG Fox, 191-210. Santa Fe, NM: School of American Research Press 
Appadurai A. 1996. Modernity at Large. Cultural Dimensions of Globalization. Minneapolis \& London: Univ. of Minnesota (French ed.)

Appadurai A. 1996. Modernity at Large: Cultural Dynamics of Globalization. Minneapolis: Univ. of Minnesota

Appadurai A. 1997. Fieldwork in the era of globalization. Anthropol.\& Humanism 22(1):1158.

Appadurai A. 2005 (1996). Après le Colonialisme: Les Conséquences Culturelles de la Globalisation. Paris: Petite Bibliothèque Payot

Assayag J. 1998. La culture comme fait social global? Anthropologie et (post)modernité. L'Homme 148:201-24

Assayag J, Bénéï V. 2000. A demeure en diaspora. Asie du Sud, Europe, Etats-Unis. L'Homme 156:15-28

Aubrée M. 2000. La diffusion du pentecôtisme brésilien en France et en Europe: le cas de l'IURD. In Les Mutations Transatlantiques des Religions, ed. C Lerat, B Rigal-Cellard, 14957. Bordeaux (France): Presses Universitaires de Bordeaux

Babès L, ed. 1996. Les Nouvelles Manières de Croire. Judaïsme, Christianisme, Islam, Nouvelles Religiosités. Paris: Les Éditions de l'Atelier 
Barou J. 1978. Travailleurs Africains en France. Rôle des Cultures d'Origine. Grenoble \& Paris: Presses universitaires de Grenoble \& Publications orientalistes de France. 162 pp.

Barth F. 1969. Ethnic Groups and Boundaries. The Social Organization of Cultural Difference. Bergen \& London: Universitetsforlaget, Allen \& Unwin. 153 pp.

Bastenier A. 1998. L'incidence du facteur religieux dans la "conscience ethnique" des immigrés marocains en Belgique. Soc. Compass 45(2):195-218

Battegay A. 1990. Commerces et commerçants étrangers dans la ville: notes bibliographiques. Cah. Séminaires 'Tech., Territ. \& Soc.' 13

Baubérot J. 1994. Pluralisme Religieux et Lä̈cités dans l'Union Européenne. Brussels: Ed. de l’Univ. de Bruxelles

Baubérot J, ed. 1994. Religions et Laïcité dans l'Europe des Douze. Paris: Syros

Baubérot J. 2006. L'Intégrisme Républicain Contre la Laicité. La Tour d'Aigues (France): Ed. de l'Aube

Bava S. 2000. Reconversions et nouveaux mondes commerciaux des Sénégalais mourides à Marseille. Hommes \& Migr.1224:46-55

Bava S. 2002. Itinéraires religieux et routes migratoires. Des pratiques religieuses des sénégalais mourides entre Marseille et Touba. $\mathrm{PhD}$ thesis. EHESS, Paris 
Bava S. 2003. De la baraka aux affaires: ethos économico-religieux et transnationalité chez les migrants sénégalais mourides. Rev. Eur. Migr. Int. 19(2):69-84

Bava S. 2003. Les Cheikh-s mourides itinérants et l'espace de la ziyâra à Marseille.

Anthropol. \& Soc. 27(1):149-66

Bava S. 2004. Le dahira urbain. Lieu de pouvoir du mouridisme. Ann. Rech. Urbaine 96:13543

Bava S. 2006. Variations autour de trois sites mourides dans la migration. Autrepart 36:10522

Bava S (w/ Pliez O). 2009. D'Al Azhar à l'économie de bazar. Itinéraires socio-économiques des "élites musulmanes" africaines au Caire. Afr. Contemp. 231(3):187-207

Bava S, Capone S. 2010. Religions transnationales et migrations: regards croisés sur un champ en movement. Autrepart 56:3-16

Bava S, Gueye C. 2001. Le grand magal de Touba: exil prophétique, migration et pèlerinage au sein du mouridisme. Soc. Compass 48(3):421-38

Bava S, Picard J. 2010. Les figures religieuses de la migration africaine au Caire. Autrepart $56: 153-70$ 
Beckford J, Levasseur M. 1986. New religious movements in Western Europe. In New Religious Movements and Rapid Social Change, ed. J Beckford, 29-59. London: Sage

Beckford JA, Tinaz N. 1997. The Nation of Islam as transnational ethno-religious movement: the case of NOI in the UK. Research Project Proposal submitted to ESRC Transnational Commmunities Project, Swindon (UK)

Berger P, ed. 2001 (1999). Le Réenchantement du Monde. Paris: Bayard

Bertoncello B, Bredeloup S. 1999. Le Marseille des marins africains. Rev. Eur. Migr. Int. 15(3):177-97

Bertoncello B, Bredeloup S. 2000. Les marins africains de Marseille: histoire d'un ancrage. Hommes \& Migr. 1224 (Mar.-Apr.):22-8

Bertoncello B, Bredeloup S. 2004. Colporteurs Africains à Marseille: Un Siècle d'Aventures. Paris: Éditions Autrement

Bonachich E, Modell J. 1980. The Economic Basis of Ethnic Solidarity. Berkeley: Univ. of California Press

Bonte P, Brisebarre AM, Gokalp A, eds. 1998. La Fête du Mouton. Un Sacrifice Musulman dans l'Espace Urbain. Paris: CNRS Ed. 
Bonte P, Brisebarre AM, Gokalp A, eds. 1999. Sacrifices en Islam. Espace et Temps d'un Rituel. Paris: CNRS Ed.

Bordes-Benayoun C. 1993. L'esprit du temps: les définitions identitaires chez les Juifs et les Arabes de France. Rev. Eur. Migr. Int. 9(3):95-118

Boubakri H. 1985. Le Petit commerce immigré du Sud Tunisien à Paris. $\mathrm{PhD}$ thesis. Univ. de Strasbourg, France, 320pp.

Boubakri H. 1999. Les entrepreneurs migrants d'Europe. Cult. \& Confl. 33-34:69-88

Boubakeur A. 2007. Islam militant et nouvelles formes de mobilisation culturelle. Arch. Sci. Soc. Relig. 139:119-38

Bowen JR. 2004. Does French Islam have borders? Dilemmas of domestication in a global relilgious field. Am. Anthropol. 106(1):43-55

Bowen JR. 2004. Beyond migration: Islam as a transnational public space. J. Ethn. Migr. Stud. 30(5):880-94

Bredeloup S. 2008. L'aventurier, une figure de la migration africaine. Cah. Int. Sociol. 125(2):281-306 
Caeiro A. 2003. The European Council for Fatwa and Research. Presented at $4^{\text {th }}$ Mediterr. Soc. and Pol. Res. Meet., Robert Schuman Centre for Advanced Studies/European University Institute, Florence \& Montecatini Terme (Italy)

Capone S. 2004. A propos des notions de globalisation et de transnationalisation. Civilis. LI(1-2):11-34

Capone S. 2010. 'Religions en migration': De l'étude des migrations internationales à 1'approche transnationale. Autrepart 56:235-59

Coleman S, Collins P, eds. 2004. Religion, Identity and Change: Perspectives on Global Transformations. Aldershot: Ashgate

Colomonos A. 2000. Eglises en Réseaux. Trajectoires Politiques entre Europe et Amériques. Paris: Presses de Sciences-Po. 315 pp.

Coyault B. 2004. Eglises issues de l'immigration dans le paysage protestant français: de la “mission en retour” à la mission commune. Inf. - Evangél. (Journal of the French Protestant Church) 5:3-18

Coyault B. 2008. Un kilombo à Paris: l'itinéraire d'une prophétesse de l'Eglise Evangélique du Congo. Arch. Sci. Soc. Relig. 143:151-73

Cesari J. 1994. Être Musulman en France. Associations, Militants et Mosquées. Aix-enProvence \& Paris: IREMAM \& Karthala. 367 pp. 
Cesari J. 1998. Musulmans et Républicains, les Jeunes, l'Islam et la France. Brussels: Complexe. 166 pp.

Cesari J. 2000. Musulmans français et intégration socio-politique. In Religion et Action dans l'Espace Public, ed. B Bréchon, B Duriez, J Ion. Paris \& Montréal: L’Harmattan. 301 pp.

Cesari J. 2004. L'Islam à l'Epreuve de l'Occident. Paris: La Découverte. 291 pp.

Clifford J. 1994. Diasporas. Cult. Anthropol. 9(3):302-38

Clifford J. 1997. Spatial practices: fieldwork, travel and the disciplining of anthropology. In Anthropological Locations. Boundaries and Grounds of a Field Science, ed. A Gupta, J Ferguson, 185-222. Berkeley: Univ. of California Press

Clifford J. 1997. Routes, Travel and Translation in the late Twentieth Century. Cambridge: Harvard Univ. Press. 408 pp.

Dassetto F, Bastenier A. 1984. L'Islam Transplanté. Vie et Organisation des Minorités Musulmanes en Belgique. Antwerpen: Epo

Dassetto F, Bastenier A, eds. 1991. Immigrations et Nouveaux Pluralismes. Brussels: De Boeck Wesmael 
Davie G, Hervieu-Léger D. 1996. Identités Religieuses en Europe. Paris: La Découverte. $335 \mathrm{pp}$.

Didem D. 2006. Attendre au purgatoire: les réseaux religieux de migrants chrétiens d'Irak en transit à Istanbul. Rev. Eur. Migr. Int. 22(3):109-34

Diop AM. 1985. Les associations murid en France. Esprit 102:197-206

Diop AM. 1990. L’émigration murid en Europe. Hommes \& Migr. 1132:21-31

Diop AM. 1990. Le mouvement associatif négro-africain en France. Hommes \& Migr. $1132: 15-20$

Diop AM. 1990. Un aperçu de l'islam négro-africain en France. Migrants-Form. 82 (Sept.)

Diop AM. 1996. Le mouvement islamique africain en Île de France. Migr. \& Soc. 8(44)

Ebaugh HR, Chafetz JS. 2000. Religion and the New Immigrants: Continuities and Adaptations in Immigrant Congregations. Walnut Creek, CA: Altamira Press

Ebaugh HR, Chafetz JS. 2002. Religion across Borders: Transnational Religious Networks. Walnut Creek, CA: Altamira Press 
Ebaugh HR, O’Brien J, Chafetz JS. 2000. The social ecology of residential patterns and membership in immigrant churches. J. Sci. Stud. Relig. 39(1):107-16

Ebaugh HR, Yang F. 2001. Transformations in new immigrant religions and their global implications. Am. Sociol. Rev. 66:269-88

Ebin V. 1990. Commerçants et missionnaires: une confrérie musulmane sénégalaise à NewYork. Hommes \& Migr. 1132:25-31

Ebin V. 1991. Migrants mourides sénégalais. Chron. Sud (ORSTOM) 4:128-31

Ebin V. 1992. A la recherche de nouveaux 'poisons.' Stratégies commerciales mourides par temps de crise. Pol. Afr. 45:86-99

Ebin V, Lake R. Camelots à New-York - les pionniers de l'immigration sénégalaise. Hommes \& Migr. 1160:32-37

Ebin V, Lake R. 1993. Les commerçants mourides à Marseille et à New-York. Regards sur les stratégies d'implantation. In Grands Commerçants d'Afrique de l'Ouest. Logiques et Pratiques d'un Groupe d'Hommes d'Affaires Contemporains, ed. E Grégoire, P Labazée, 101-23. Paris: Karthala-ORSTOM

Ebin V, Lake R. 1995. International networks of trading diaspora: the Mourides of Sénégal abroad. In La Ville à Guichets Fermés? Itinéraires, Réseaux et Insertion Urbaine, ed. $\mathrm{P}$ Antoine, AB Diop, 323-36. Dakar \& Paris: IFAN-ORSTOM 
Ebin V, Lake R. 1995. Women, saints and strategies: the expanding role of Senegalese women in international trade. Mondes en Dév. XXIII(91):113-15

Ebin V, Lake R. 1996. Making room versus creating space: the construction of spatial categories by itinerant Mouride traders. In Making Muslim Space in North America and Europe, ed. B Daly Metcalf, 92-109. Berkeley \& L.A.: Univ. of California Press

Fancello S. 2003. Les politiques identitaires d'une Eglise africaine internationale: the Church of Pentecost (Ghana). Cah. d'Etudes Afr. XLIII-4(173):857-81

Fancello S. 2005. Réseaux migratoires et structures de pouvoir: la Church of Pentecost face aux communautés francophones. In Entreprises Religieuses Transnationales en Afrique de l'Ouest, ed. L Fourchard, A Mary, R Otayek, 113-36. Paris: IFRA-Karthala

Fancello S. 2009. Migration et plurilinguisme: 'parler en langues' dans les Eglises africaines en Europe. Soc. Compass 56(3):387-404

Friedman J. 1994. Cultural Identity and Global Process. London: Sage. 270 pp.

Gaspard F. 1992. Assimilation, insertion, intégration: les mots pour 'devenir français.' Hommes \& Migr. 1154:14-23

Geertz C. 1973. The Interpretation of Cultures: Selected Essays. New York: Basic Books. $470 \mathrm{pp}$. 
Geertz C. 2006. La religion, sujet d'avenir. In Les Sciences Sociales en Mutation, ed. M Wieviorka. Paris: Ed. Sciences Humaines. 624 pp.

Geisser V. 2001. Marseille, capitale de l'islam méridional. La Medina 7:24-32

Girard A, Stoezel J. 1953. Français et Immigrés. Vol. 1: L'Attitude Française, l'Adaptation des Italiens et des Polonais. Paris: PUF/INED 19. 531 pp.

Glick-Schiller N. 1999. Transmigrants and nation-states: something old and something new in the U.S. immigrant experience. In Handbook of International Migration: The American Experience, ed. C Hirschman, P Kasinitz, J DeWind, 94-119. New York: Russell Sage

Glick-Schiller N, Basch L, Szanton Blanc C, eds. 1992. Towards a Transnational Perspective on Migration: Race, Class, Ethnicity, and Nationalism Reconsidered. New York: New York Academy of Sciences/Annals 645. 259pp.

Glick-Schiller N, Basch L, Szanton Blanc C, 1995. From immigrant to transmigrant: theorizing transnational migration. Anthropol. $Q .68(1): 48-63$

Glick-Schiller N, Levitt P. 2004. Conceptualizing simultaneity: a transnational social field perspective on society. Int. Migr. Rev. 38(3):1002-39

Glick-Schiller N, Çaǵlar A, Guldbrandsen TC. 2006. Beyond the ethnic lens: locality, globality, and born-again incorporation. Am. Ethnol. 33(4):612-33 
Göle N. 2002. Islam in public: new visibilities and new imaginaries. Public Cult. 14(1):17390

Grafmeyer Y. 1994. Sociol. Urbaine Paris: Nathan. 127 pp.

Granovetter M. 1985. Economic action and social structures: the problem of embeddedness. Am. J. Sociol. 91(3):481-93

Granovetter M. 1995. The economic sociology of firms and entrepreneurs. In The Economic Sociology of Immigration. Essays on Networks, Ethnicity and Entrepreneurship, ed. A Portes, 4:128-65. New York: Russel Sage Foundation.

Granovetter M. 2000. Le Marché Autrement: les Réseaux dans l'Economie. Paris: Desclée de Brouwer

Guarnizo LE, Smith MP. 1998. The locations of transnationalism. In Comparative Urban and Community Vol. 6: Research Transnationalism from Below, ed. LE Guarnizo, MP Smith, 1:334. New Brunswick, NJ: Transaction Publishers. 316 pp.

Gueye C. 2002. Touba. La Capitale des Mourides. Paris: Karthala

Haenni P. 2005. L'Islam de Marché. Paris: Ed. du Seuil 
Hagan JM. 2008. Migration Miracle. Faith, Hope and Meaning on the Undocumented Journey. Harvard Univ. Press. 238 pp.

Hagan JM, Ebaugh HR. 2003. Calling upon the sacred: migrants' use of religion in the migration process. Int. Migr. Rev. 34(4):1145-62

Hall S. 1998. The local and the global: globalization and ethnicity. In Culture, Globalization and the World-System. Contemporary Conditions for the Representation of Identity, ed. AD King, 19-39. Minneapolis: Univ. of Minnesota Press

Hannerz U. 1980. Exploring the City: Inquiries Toward an Urban Anthropology. New York: Columbia Univ. Press

Hannerz U. 1989. Notes on the global ecumene. Public Cult. 1(2):66-75

Hannerz U. 1996. Transnational Connections: Culture, People, Places. London: Routledge

Harris H. 2006. Yoruba in Diaspora. An African Church in London, London: Palgrave Macmillan

Hervieu-Léger D. 1993. La Religion pour Mémoire. Paris: Ed. du Cerf. 273 pp.

Kastoryano R. 1986. Etre Turc en France. Réflexions sur Familles et Communauté. Paris:

L'Harmattan. 207 pp. 
Kepel G. 1987. Les Banlieues de l'Islam. Paris: Ed. du Seuil. 424 pp.

Kepel G. 1991. La Revanche de Dieu. Chrétiens, Juifs et Musulmans à la Reconquête du Monde. Paris: Ed. du Seuil

Kepel G. 1994. A l'Ouest d'Allah. Paris: Ed. du Seuil. 335 pp.

Kepel G. 2000. Expansion et Déclin de l'Islamisme. Paris: Gallimard

Kepel G, Richard Y. 1990. Intellectuels et Militants de l'Islam Contemporain. Paris: Ed. du Seuil. $287 \mathrm{pp}$.

Kounkou D. 2000. Les églises chrétiennes d'expression africaine en France. In Chrétiens d'Outre-mer en Europe. Un Autre Visage de l'Immigration, ed. M Spindler, A Lenoble-Bart, 219-27. Paris: Karthala

Kounkou D, Poulat E, eds. 2004. Les Discriminations Religieuses en France. Paris: L'Harmattan. 190 pp.

Kuczynski L. 2002. Les Marabouts Africains à Paris. Paris: CNRS Ed. 439 pp.

Kuczynski L, Razy E. 2009. Anthropologie et migrations africaines en France. Une généalogie des recherches. Rev. Eur. Migr. Int. 25(3):79-100 
Lacoste Dujardin C. 1997. Transmission religieuse et migration: l'islam identitaire des filles des maghrébins en France. Soc. Compass 41(1):163-70

Levitt P. 1998. Local-level global religion: U.S.-Dominican migration. J. Sci. Stud. Relig. $37: 74-89$

Levitt P. 2001a. The Transnational Villagers. Berkeley: Univ. of California Press

Levitt P. 2001b. Between God, ethnicity and country: an approach to the study of transnational religion. Presented at Transnatl. Migr. Conf.: Comp. Res. \& Theor. Perspectives. Part II, Princeton Univ.

Levitt P. 2001c. Transnational migration: taking stock and future directions. Glob. Netw. 1(3):195-216

Levitt P. 2003. 'You know, Abraham was really the first immigrant': religion and transnational migration. Int. Migr. Rev. 37(3):847-73

Levitt P. 2004. Redefining the boundaries of belonging: the institutional character of transnational religious life. Sociol. Relig. 65(1):1-18

Levitt P. 2007. God Needs No Passport: Immigrants and the Changing Religious Landscape. New York: The New Press 
Levitt P, Glick-Schiller N. 2004. Conceptualizing simultaneity: a transnational social field perspective on society. Int. Migr. Rev. 38(3):1002-39

Luca N. 2002. De l'état des religions sur la mondialisation. Arch. Sci. Soc. Relig. 120:47-53

Luca N. 2008. Entre essentialisation sectaire et essentialisme ethnique. Arch. Sci. Soc. Relig. $143: 235-51$

Ma Mung E. 1992. Dispositif économique et ressources spatiales: une économie de diaspora. Rev. Eur. Migr. Int. 8(3):175-93

Ma Mung E. 1994. L’entreprenariat ethnique en France. Sociol. Trav. 2:185-209

Ma Mung E. 1998. Intégration locale et territoire global. Cult. Mouv. 10

Ma Mung E. 1999. La dispersion comme ressource. Cult. \& Confl. 33-34:89-103

Ma Mung E. 2000. La Diaspora Chinoise: Géographie d'une Migration. Paris: Ophrys

Mary A. 2000. L'anthropologie au risque des religions mondiales. Anthropol. \& Soc. 24(1):117-35

Mary A. 2000. Anges de Dieu et esprits territoriaux: une religion africaine à l'épreuve de la transnationalisation. Autrepart 14:71-89 
Mary A. 2005. Métissage and bricolage in the making of African Christian identities. Soc.

Compass 52(3):281-94

Mary A. 2008. Africanité et christianité: une interaction première. Arch. Sci. Soc. Relig. $143: 9-30$

Maskens M, Noret J. 2007. La nouvelle Jérusalem. Eléments d'histoire et de sociologie d'une église pentecôtiste en Belgique. Le Figuier 1:117-37

Maskens M, Noret J. 2009. Migration et pentecôtisme à Bruxelles. Expériences croisées. Arch. Sci. Soc. Relig. 143:49-68

Meintel D, Leblanc MN. 2003. La mobilité du religieux à l'ère de la globalisation. Anthropol. \& Soc. 27(1):5-11

Michel A. 1956. Les Travailleurs Algériens en France. Paris: CNRS

Noiriel G. 1988. Le Creuset Français: Histoire de l'Immigration. Paris: Ed. du Seuil. 437 pp.

Péraldi M. 1999. Marseille: réseaux migrants transfrontaliers, places marchandes et économies de bazar. Cult. \& Confl. 33-34:51-67

Péraldi M, ed. 2001. Cabas et Containers. Activités Marchandes Informelles et Réseaux Migrants Transfrontaliers. Paris: Maisonneuve et Larose/Maison méditerranéenne des Sciences de l'Homme. 361 pp. 
Portes A. 1999. La mondialisation par le bas. L'émergence de communautés transnationales. Actes Rech. Sci. Soc. 129:15-25

Poutignat P, Streiff-Fenart J. 1995. Théories de l'Ethnicité. Paris: PUF. 270 pp.

Quiminal C. 1991. Gens d'Ici, Gens d'Ailleurs. Migrations Soninké et Transformations Villageoises. Paris: Christian Bourgeois. 222 pp.

Quiminal C, Timera M. 2002. 1974-2002, Les mutations de l'immigration ouest-africaine. Hommes \& Migr. 1239:19-32

Odgers Ortiz O, Ruiz Guadalajara JC. 2009. Migracion y Creencias: Pensar las Religiones en Tiempos de la Movilidad. México: Porrúa/El Colef/Colegio de San Luis. 557 pp.

Riccio B. 2001. From 'ethnic group' to 'transnational communauties'? Senegalese migrants' ambivalent experiences and multiple trajectories. J. Ethn. Migr. Stud. 27(4):583-99

Riccio B. 2006. Transmigrants mais pas nomades. Transnationalisme mouride en Italie. Cah. d'Etudes Afr. 181:95-114

Roy O. 1992. L'Echec de l'Islam Politique. Paris: Ed. du Seuil Roy O. 2002. L'Islam Mondialisé. Paris: Ed. du Seuil 
Saint-Blancat C. 1995. Une diaspora musulmane en Europe. Arch. Sci. Soc. Relig. 92:9-24

Saint-Blancat C. 1997. L'Islam de la Diaspora. Paris: Ed. Bayard. 196 pp.

Salem G. 1981. De Dakar à Paris, des diasporas d'artisans et de commerçants. Etude sociogéographique du commerce sénégalais en France. $\mathrm{PhD}$ thesis, EHESS, Paris

Salem G. 1981. De la brousse sénégalaise au Boul'Mich: le système commercial mouride en France. Cah. d'Etudes Afr. 21(81-83):267-88

Sassen S. 1994. L'ethnicité et l'espace dans la ville globale. Ann. Rech. Urbaine 64:90-95

Sassen S. 1996. La Ville Globale: New York, Londres, Tokyo. Paris: Descartes. 530 pp.

Sayad A. 1992. L'Immigration ou les Paradoxes de l'Altérité. Brussels: De Boeck Univ.. 331 pp.

Sayad A. 1999. La Double Absence. Des Illusions de l'Emigré aux Souffrances de l'Immigré. Paris: Ed. du Seuil. 438 pp.

Schmidt di Friedberg O. 1993. Débuts d'une réalité: l'Islam en Italie. In L'Islam et les Musulmans dans le Monde vol. 1, ed. M Arkoun, R Leveau, B El Jisr, 179-223. Beirut: Hariri Cultural Center 
Schmidt di Friedberg O. 1994. Islam, Solidarietà e Lavoro. I Muridi Senegalesi in Italia.

Torino: Ed. della Fondazione Giovanni Agnelli

Schmidt di Friedberg O. 1994. Le réseau sénégalais mouride en Italie. In Exils et Royaumes. Les Appartenances au Monde Arabo-musulman Aujourd'hui, ed. G Kepel. Paris: Presses de la FNSP

Schmidt di Friedberg O. 1995. Les Burkinabé et les Sénégalais dans le contexte de l'immigration ouest-africaine en Italie. Mondes en Dév. 23(91):67-80

Schmidt di Friedberg O. 1998. La cohabitation dans le Nord de l'Italie. Marocains et Sénégalais à Turin et à Brescia. Migr. Soc. 10(55):87-107

Schmidt di Friedberg O. 1999. Immigré et entrepreneur: un choix inévitable? Les Marocains à Milan. Studi Emigr./Migr. Stud. 36(136):677-97

Schnapper D. 1991. La France de l'Intégration: Sociologie de la Nation en 1990. Paris: Gallimard. 374 pp.

Schnapper D. 1993. Le sens de l'ethnico-religieux. Arch. Sci. Soc. Relig. 31:149-63

Spire A. 1999. De l'étranger à l'immigré. La magie sociale d'une catégorie statistique. Actes Rech. Sci. Soc. 129:50-56

Tarrius A. 1989. Anthropologie du Mouvement. Caen (France): Paradigme. 176 pp. 
Tarrius A. 1992. Les Fourmis d'Europe: Migrants Riches, Migrants Pauvres et Nouvelles Villes Internationales. Paris: L'Harmattan. 207 pp.

Tarrius A. 1995. Arabes de France dans l'Economie Mondiale Souterraine. La Tour d'Aigues (France): Ed. de l'Aube. 219 pp.

Tarrius A. 1996. Territoires circulatoires et espaces urbains. Ann. Rech. Urbaine 59-60: pp.50-59

Tarrius A (with Missaoui L). 2001. Les Nouveaux Cosmopolitismes: Mobilités, Identités, Territoires. La Tour d'Aigues (France): Ed. de l'Aube. 224 pp.

Tarrius A. 2003. La Mondialisation par le Bas, les Nouveaux Nomades des Economies Souterraines. Paris: Ed. Balland. 168 pp.

Tarrius A. 2007. La Remontée des Sud, Afghans et Marocains en Europe Méridionale. La Tour d'Aigues (France): Ed. de l'Aube, 217 pp.

Ter Haar G. 1998. Halfway to Paradise. African Christians in Europe. Cardiff (UK): Cardiff Academic Press. 220 pp.

Ter Haar G. 2008. Enchantment and identity. African Christians in Europe. Arch. Sci. Soc. Relig. 143:31-48 
Timera A. 1996. Les Soninkés en France. D’une Histoire à l'Autre. Paris: Karthala. 244 pp.

Tribalat M, ed. 1991. Cent Ans d'Immigration, Etrangers d'Hier, Français d'Aujourd'hui, Apport Démographique, Dynamique Economique et Familiale de l'Immigration. Paris: PUF/INED. 301 pp.

Waldinger R. 1994. The making of an immigrant niche. Int. Migr. Rev. 28:3-30

Van Hove H. 1999. L’émergence d'un 'marché spirituel'. Soc. Compass, 46(2):161-72 